\title{
Contribution and Trend to Quality Research-a literature review of SERVQUAL model from 1998 to 2013
}

\author{
Ya Lan WANG ${ }^{1}$, Tainyi LUOR ${ }^{1}$, Pin LUARN ${ }^{2}$, Hsi Peng LU ${ }^{2}$ \\ ${ }^{1}$ Graduate Institute of Management, School of Management, National Taiwan University of \\ Science and Technology, Taipei, Taiwan, R.O.C \\ ${ }^{2}$ Department of Business Administration, National Taiwan University of Science and Tech- \\ nology, Taipei, Taiwan, R.O.C \\ carol_yl_wang@yahoo.com.tw,dr.luor@gmail.com,luarn@ba.ntust.com.tw, \\ hsipeng@cs.ntust.com.tw
}

While many past studies focus on service quality research, especially using the "SERVQUAL", little is known about the mechanics of this model. Motivated by the need to gauge the contribution of the SERVQUAL model, this study reviews 367 SSCI and SCI articles that are related to the SERVQUAL model from 1998 to 2013. We identify key factors and conduct a survey to search for related articles in the Institute for Scientific Information (ISI) Web of Science (WOS) database. Research contributions are measured, ranked, and presented based on quantity and quality metrics. The trends of SERVQUAL model research from our results are discussed. This study shows that the SERVQUAL model was one of the hot research topics by academic researchers and significantly contributed to service quality research.

Keywords: SERVQUAL model, service quality, quality research, research contribution

\section{1} Introduction

SERVQUAL is the abbreviation used for "Service Quality." The SERVQUAL scale was developed based on the ten requisites of quality service in "Conceptual Model of Service Quality_PZB Method" [1]. In 1988, PZB conducted further research [2] and categorized their findings into five determinants: Tangibles, Reliability, Responsiveness, Assurance, and Empathy as the SERVQUAL scale. It provides a complete scoring system to every industry, to assist management with credibility and efficiency, and to serve the purpose of service improvement.

This study differs from traditional literature reviews. Traditional reviews design SERVQUAL scales according to the PZB model and measure the clients' satisfaction of service quality. Our research aims to generalize and probe changes in the research on service quality and the areas of analysis over the past fifteen years (from 1998 to 2013), and to serve as an overview to researchers interested in service quality [3].

When choosing references, most researchers value the impact factor as an influential criterion in addition to research methods and theories. We use the ISI WOS database as our major research tool. The ISI WOS database collects all recent papers in the Sciences Citation Index (SCI) and Social Sciences Citation Index (SSCI). The metrics for assessing research contribution for academics, departments, journals, and conferences usually have two dimensions: quantity and quality. The quantity can be measured by the number of related publications while the quality can be measured by the number of citations of the papers [4]. A metric that combines quantity and quality into a single number called Hirsch Index has been proposed to measure contribution of a researcher [5].

We analyze past SERVQUAL articles with four major perspectives: time (number of articles published and times cited each year), geography (country and research institution), productivity (researchers and journals), and impact (number of citations, research fields, and article characteristics) in preparation for future research.

This paper is organized as follows: we discuss our research methods with the scope of study and the metrics of research contribution. The results are presented and discussed based on different factors. We conclude our paper with trends that correlated to our re- 
sults and future work.

\section{Research Methods}

In this Section we present our research methods with the scope or our research, and metrics for research contribution.

\subsection{Scope of the Study}

Our study uses keywords to search the ISI WOS database. It includes 367 SERV-QUAL model related articles in $167 \mathrm{SCI}$ and SSCI journals. The result shows that there is an increasing interest in the area of service quality (Figure 1). In particular, the number of articles and the number of citations suddenly increased between 2009 and 2011. Since then, the number of articles on the follow-up discussion regarding this topic has dropped marginally but the times cited have increased. Thus, it can be seen that service quality remains a significant research area among service-related articles.

\section{Number of articles and times cited publications (1998-2013)}

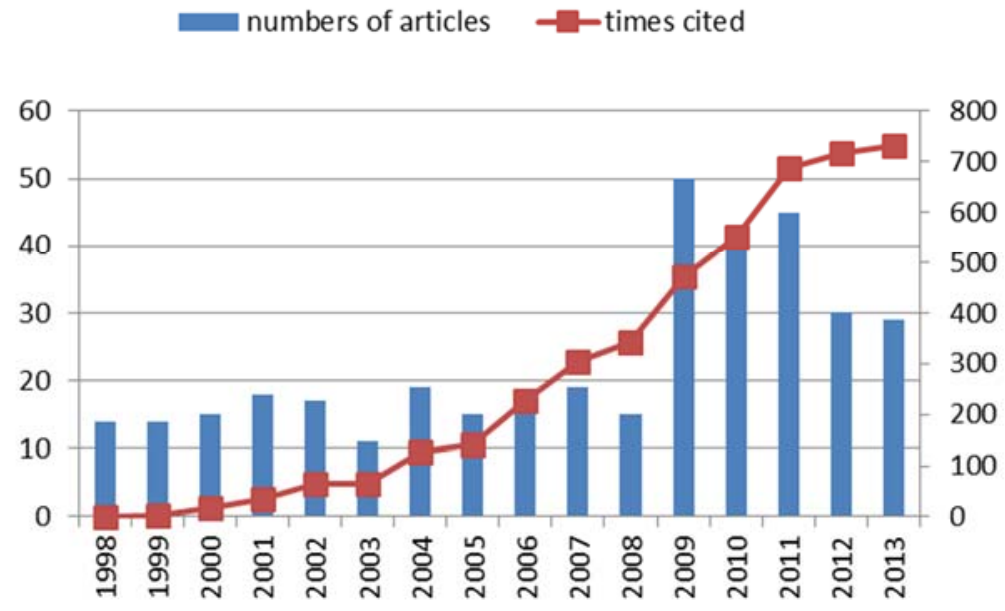

Fig. 1. Number of Articles and Times Cited Publications (1998-2013)

\subsection{Assessment of Research Contribution} Quantity and quality of research articles are both important metrics for measuring research contribution. We calculate the number of SERVQUAL articles and times they are cited from the ISI WOS database to measure the "contribution" of authors and articles published. Times cited is a crucial index in measuring contribution of the articles, while the number of articles can reflect important trends in the relevant research, which helps generate value for study and research [6]. By generalizing and analyzing their emphasis, we can see (1) the productivity of the journal and the author, (2) the updates of publications as the reference for research expansibility, and (3) the impact on the field by the times cited of the author.

\section{Research Results}

The following shows our surveys on SERVQUAL model by research field, journal, country, institution, researcher, number of citations, and article characteristic.

3.1 Frequency of the Research on SERVQUAL Model by Research Field

We analyze the research fields of the articles (Table 1). According to the ISI WOS database, there are 46 different fields. The articles investigated might overlap across multiple fields. The first five items of the top ten fields cover peoples' lifestyles, core topics of corporations, and life trends. Among these, the most discussed field is the MANAGEMENT field. The information age also results in the rapid development of e-commerce and related technologies. It not only helps innovation in service values, but also brings about changes in business models. Corresponding- 
ly, it is also influential in customer satisfaction. Whether this can be converted to profits for companies has been a topic of discussion for many recent papers. Even traditional industries are participating in service quality initiatives, and are no longer using production and yields to measure performance. In general, the number of times cited in the top ten fields can indicate changes in peo- ple's overall attitudes towards life and value systems. For instance, an emphasis on health leads to the popularity of the leisure and tourism industry, in which the customers also value service quality. Throughout all the research fields, we can also see the diversity of articles.

Table 1. The Top Ten Categories According to Numbers of WOS Articles (1998-2013)

\begin{tabular}{|ll|c|c|}
\hline \multicolumn{1}{|c|}{ Research Field } & $\begin{array}{c}\text { Number of } \\
\text { Articles }\end{array}$ & $\%$ \\
\hline 1. & Management & 156 & 42.5 \\
\hline 2. & Business & 62 & 16.9 \\
\hline 3. & Information science library science & 34 & 9.3 \\
\hline 4. & Computer science information systems & 27 & 7.4 \\
\hline 5. & Hospitality; leisure sport; tourism & 26 & 7.1 \\
\hline 6. & Operations research management science & 17 & 4.6 \\
\hline 7. & Computer science artificial intelligence & 13 & 3.5 \\
\hline 8. & Health care sciences services & 12 & 3.3 \\
\hline 9. & Engineering industrial & 12 & 3.3 \\
\hline 10. & Nursing & 11 & 3.0 \\
\hline
\end{tabular}

3.2 Frequency of the Research on SERVQUAL Model by Journal, Country, Institution, and Researcher

The top ten journals of SERVQUAL publications are shown in Table 2. There were 367 articles published in 167 journals (in ISI WOS database), 140 articles (39\%) of which are in the top ten journals. There is an emphasis on articles in the service categories in the practical application and research areas. This emphasis is constant over time and articles have been published and discussed in several professional areas.

Table 2. The Top Ten Journals of SERVQUAL Publications (1998-2013)

\begin{tabular}{|ll|c|c|}
\hline \multicolumn{1}{|c|}{ Journal title } & $\begin{array}{c}\text { Number } \\
\text { of articles }\end{array}$ & \% \\
\hline 1. & Total quality management business excellence & 37 & 10.1 \\
\hline 2. & Service industries journal & 18 & 4.9 \\
\hline 3. & African journal of business management & 14 & 3.8 \\
\hline 4. & Managing service quality & 12 & 3.3 \\
\hline 5. & Total quality management & 12 & 3.3 \\
\hline 6. & Tourism management & 11 & 3.0 \\
\hline 7. & International journal of service industry management & 10 & 2.7 \\
\hline 8. & Journal of business research & 10 & 2.7 \\
\hline 9. & Expert systems with applications & 8 & 2.2 \\
\hline 10. & Quality quantity & 8 & 2.2 \\
\hline
\end{tabular}

The top ten countries with the most SERVQUAL publications are shown in Table 3. A total of 52 countries were involved in the publication of articles; 305 (82.3\%) articles are from the top 10 countries, while the remaining $17.7 \%$ are from the other 42 coun- 
tries. US and Europe remain the leading countries on SERVQUAL model re-search. It also shows three Asian countries (Taiwan,
China and South Korea) have 93 (25.3\%) articles in total, indicating the significant contribution and interest of Asia in this field.

Table 3. Top Ten Countries of SERVQUAL Publications (1998-2013)

\begin{tabular}{|c|c|c|}
\hline Country & $\begin{array}{l}\text { Number } \\
\text { of articles }\end{array}$ & $\%$ \\
\hline 1. USA & 103 & 28.1 \\
\hline 2. $\quad$ TAIWAN * & 58 & 15.8 \\
\hline 3. ENGLAND & 29 & 7.9 \\
\hline 4. $\quad$ TURKEY & 24 & 6.5 \\
\hline 5. $\quad$ PEOPLE'S REPUBLIC OF CHINA* & 22 & 6.0 \\
\hline 6. $\quad$ SPAIN & 19 & 5.2 \\
\hline 7. $\quad$ BRAZIL & 15 & 4.1 \\
\hline 8. $\quad$ SOUTH KOREA* & 13 & 3.5 \\
\hline 9. $\quad$ AUSTRALIA & 11 & 3.0 \\
\hline 10. GREECE & 11 & 3.0 \\
\hline
\end{tabular}

We analyze the SERVQUAL articles by active research institution, There are 446 institutional contributions, with $14.4 \%$ of these coming from the top ten institutions. The re- sult is shown in Table 4. We find that the result by research institution is consistent with the result by country.

Table 4. Top Ten Institutional Contributors of SERVQUAL Publications (1998-2013)

\begin{tabular}{|ll|c|c|}
\hline \multicolumn{1}{|c|}{ Institutional Contributors } & $\begin{array}{c}\text { Number } \\
\text { of articles }\end{array}$ & \% \\
\hline 1. & EASTERN MEDITERRANEAN UNIV (TURKEY) & 6 & 1.6 \\
\hline 2. & HONG KONG POLYTECH UNIV (CHINA) & 6 & 1.6 \\
\hline 3. & NATL CHIAO TUNG UNIV (TAIWAN) & 6 & 1.6 \\
\hline 4. & FATIH UNIVERSITY (TURKEY) & 5 & 1.4 \\
\hline 5. & FLORIDA STATE UNIV (USA) & 5 & 1.4 \\
\hline 6. & NATL TAIWAN UNIVERSITY SCI TECHNOLOGY & 5 & 1.4 \\
\hline 7. TAIWAN) & PENN STATE UNIVERSITY (USA) & 5 & 1.4 \\
\hline 8. & TEXAS A M UNIVERSITY (USA) & 5 & 1.4 \\
\hline 9. & UNIVERSITY GRANADA (SPAIN) & 5 & 1.4 \\
\hline 10. & YONSEI UNIVERSITY (SOUTH KOREA) & 5 & 1.4 \\
\hline
\end{tabular}

As for the top individual contributors on SERVQUAL research, the top ten among the 872 authors are shown in Table 5. There does not seem to have a strong correlation between number of articles and number of cita- tions for individual researchers. It raises further questions on how to effectively evaluate research contribution based on quantitative and qualitative metrics. We discuss our thoughts on this in our conclusion.

Table 5. The Top Ten Researchers of SERVQUAL Publications (1998-2013)

\begin{tabular}{|ll|c|c|}
\hline \multicolumn{2}{|c|}{ Researcher/Institution } & $\begin{array}{c}\text { Number } \\
\text { of articles }\end{array}$ & $\%$ \\
\hline 1. & Chen S. H. (CHUNG-YUAN UNIVERSITY, TAIWAN) & 5 & 1.4 \\
\hline 2. & Kara A. (PENN STATE UNIVERSITY, USA) & 5 & 1.4 \\
\hline
\end{tabular}




\begin{tabular}{|ll|c|c|}
\hline 3. & $\begin{array}{l}\text { Nadiri H. (EASTERN MEDITERRANEAN UNIVER- } \\
\text { SITY, TURKEY) }\end{array}$ & 5 & 1.4 \\
\hline 4. & $\begin{array}{l}\text { Prybutok V. R. (UNIVERSITY OF NORTH TEXAS, } \\
\text { USA) }\end{array}$ & 4 & 1.1 \\
\hline 5. & Tseng M. L.( LUNGHWA UNIVERSITY, TAIWAN) & 4 & 1.1 \\
\hline 6. & Bienstock C. C. ( RADFORD UNIVERSITY, USA) & 3 & 0.82 \\
\hline 7. & Carr C. L. (CALFORNIA STATE UNIVERSITY, USA) & 3 & 0.82 \\
\hline 8. & $\begin{array}{l}\text { Chen K. K. (NATIONAL TAIWAN OCEAN UNIVER- } \\
\text { SITY, TAIWAN) }\end{array}$ & 3 & 0.82 \\
\hline 9. & Hussain K. (TAYLOR'S UNIVERSITY, MALAYSIA) & 3 & 0.82 \\
\hline 10. & $\begin{array}{l}\text { Jiang J. J. (NATIONAL TAIWAN UNIVERSITY, } \\
\text { TAIWAN) }\end{array}$ & 3 & 0.82 \\
\hline
\end{tabular}

\subsection{The Top Ten Most Frequently Cited SERVQUAL Articles}

Times Cited is known as a crucial index in measuring quality contribution of the articles. In Table 6, we analyze the top ten most cited articles. They are generalized ac-cording to times, cited from low to high, and listed by authors, times cited, articles, and journal. The most cited article is "Antecedents of B2C channel satisfaction and preference: Validating e-commerce metrics" by Brady and Cronin [7], with 269 citations. It belongs to the e-business category, and measures customer satisfaction in e-business by TAM, TCA, and service quality. This article was cited 269 times in total, and 25.79 times annually, representing a share of $20.8 \%$. It is considered as a classic among articles on service quality, and shows by empirical research that the satisfaction of clients requires reliability, re- sponsiveness, and empathy.

The second most cited article is "Quality, Satisfaction and behavioral intentions" by Baker and Crompton [8], with a percentage of times cited of $20.7 \%, 254$ in total, and 11.80 times annually. The third is " $\mathrm{A}$ comprehensive framework for service quality: An investigation of critical conceptual and measurement issues through a longitudinal study" by Dabholkar, Shepherd, and Thorpe [9], with 117 times cited and 11.8 times annually. The top two most cited articles, as shown in Table 6 , are cited more than 200 times. The top 3-6 articles are cited more than 100 times while 7-10 are cited at least 70-95 times. Articles related to electronic information or e-commerce account for a third of the top ten articles. It can be seen that the research on SERV-QUAL is often related to daily lives and is a must-read for people.

Table 6. The Top Ten Frequently Cited SERVQUAL Publications (1998-2013)

\begin{tabular}{|c|l|c|l|l|}
\hline Rank & \multicolumn{1}{|c|}{ Authors } & $\begin{array}{c}\text { Times } \\
\text { Cited }\end{array}$ & \multicolumn{1}{|c|}{ Article title } & Journal \\
\hline 1 & $\begin{array}{l}\text { Devaraj,S., Fan,M., } \\
\text { and Kohli R. (2002) } \\
{[10]}\end{array}$ & 269 & $\begin{array}{l}\text { Antecedents of B2C channel } \\
\text { satisfaction and preference: } \\
\text { Validating e-commerce met- } \\
\text { rics }\end{array}$ & $\begin{array}{l}\text { Information } \\
\text { Systems Re- } \\
\text { search }\end{array}$ \\
\hline 2 & $\begin{array}{l}\text { Dabholkar, P. A., } \\
\text { Shepherd, C. D., and } \\
\text { Thorpe, D. I. (2000) } \\
\text { [8] }\end{array}$ & 254 & $\begin{array}{l}\text { Quality, Satisfaction and be- } \\
\text { havioural intentions }\end{array}$ & $\begin{array}{l}\text { Annals Of } \\
\text { Tourism Re- } \\
\text { search }\end{array}$ \\
\hline 3 & $\begin{array}{l}\text { Dabholkar, P. A., } \\
\text { Shepherd, C. D., and } \\
\text { Thorpe, D. I. (2000) } \\
\text { [9] }\end{array}$ & 177 & $\begin{array}{l}\text { A comprehensive framework } \\
\text { for service quality: An inves- } \\
\text { tigation of critical conceptual } \\
\text { and measurement issues } \\
\text { through a longitudinal study }\end{array}$ & $\begin{array}{l}\text { Journal Of Re- } \\
\text { tailing[11] }\end{array}$ \\
\hline
\end{tabular}




\begin{tabular}{|c|l|c|l|l|}
\hline 4 & $\begin{array}{l}\text { Mentzer, J. T., Flint, } \\
\text { D. J., and Hult, T. } \\
\text { M. (2001) [11] }\end{array}$ & 152 & $\begin{array}{l}\text { Logistics service quality as a } \\
\text { segment-customized process }\end{array}$ & $\begin{array}{l}\text { Journal Of } \\
\text { Marketing }\end{array}$ \\
\hline 5 & $\begin{array}{l}\text { Collier, J. E. and } \\
\text { Bienstock, C. C. } \\
(2006) \text { [12] }\end{array}$ & 114 & $\begin{array}{l}\text { Measuring service quality in } \\
\text { e-retailing }\end{array}$ & $\begin{array}{l}\text { Journal Of } \\
\text { Service Re- } \\
\text { search }\end{array}$ \\
\hline 6 & $\begin{array}{l}\text { Brady, M. K., Cro- } \\
\text { nin, J. J., and Brand, } \\
\text { R. R. (2002) [13] }\end{array}$ & 113 & $\begin{array}{l}\text { Performance-only measure- } \\
\text { ment of service quality: A } \\
\text { replication and extension }\end{array}$ & $\begin{array}{l}\text { Journal Of } \\
\text { Business Re- } \\
\text { search }\end{array}$ \\
\hline 7 & $\begin{array}{l}\text { Jiang, J. J., Klein, } \\
\text { G., and Carr, C. L. } \\
\text { (2002) [14] }\end{array}$ & 94 & $\begin{array}{l}\text { Measuring information sys- } \\
\text { tem service quality: Servqual } \\
\text { from the other side }\end{array}$ & MIS Quarterly \\
\hline 8 & $\begin{array}{l}\text { Barnes, S. J. and } \\
\text { Vidgen, R. (2001) } \\
\text { 15] }\end{array}$ & 86 & $\begin{array}{l}\text { An evaluation of cyber- } \\
\text { bookshops: The webqual } \\
\text { method }\end{array}$ & $\begin{array}{l}\text { International } \\
\text { Journal Of } \\
\text { Electronic } \\
\text { Commerce }\end{array}$ \\
\hline 9 & $\begin{array}{l}\text { Cao, M., Zhang, Q. } \\
\text { Y., and Seydel, J. } \\
\text { (2005) [16] }\end{array}$ & 77 & $\begin{array}{l}\text { B2C e-commerce web site } \\
\text { quality: An empirical exami- } \\
\text { nation }\end{array}$ & $\begin{array}{l}\text { Industrial } \\
\text { Management } \\
\text { \& Data Sys- } \\
\text { tems }\end{array}$ \\
\hline 10 & $\begin{array}{l}\text { Wakefield, K. L. and } \\
\text { Blodgett, J. G. } \\
\text { (1999) [17] }\end{array}$ & 76 & $\begin{array}{l}\text { Customer response to intan- } \\
\text { gible and tangible service } \\
\text { factors }\end{array}$ & $\begin{array}{l}\text { Psychology \& } \\
\text { Marketing }\end{array}$ \\
\hline
\end{tabular}

3.4 Frequency of Research by SERVQUAL Article Characteristic

In this Section we look into the article characteristics of the studied SERVQUAL papers. Table 7 describes these characteristics and their definitions [6]. We analyze all the studied articles, classify them into five categories and list the top 30 according to the times cited of the articles in SERVQUAL model (Appendix A). We also sum the number of articles from different years according to different categories (Table 8).

The most common type of article is EMPIRICAL, where most articles would use SERVQUAL scales to measure the determi- nants of service quality, which is indicated by the questionnaire analysis of the five determinants of PZB. This not only measures client satisfaction but also applies the SERVQUAL model to measure the staff's understanding of service quality to serve the purpose of service improvement. Some scholars propose that the use of this scale should be improved according to different industries so that customers' needs are better perceived. For the articles in the REVIEW category, which are not in the top 30, they can be viewed as being representative of the total picture of SERVQUAL research by scholars, as is this paper.

Table 7. SERVQUAL Article Characteristics

\begin{tabular}{|ll|ll|}
\hline \multicolumn{2}{|c|}{ Category } & \multicolumn{2}{c|}{ Definition } \\
\hline 1. & EMPIRICAL & (1) & Development and testing of hypotheses. \\
& & (2) & Debate on results as they are related to theoretical aspects. \\
& & (3) & Methodological or managerial issues. \\
\hline 2. & REVIEW & (1) & Combine previous work and discuss critical problems. \\
& & (2) & Include articles' book reviews. \\
\hline 3. & THEORY & (1) & Introduction of conceptual structure. \\
& & (2) & Models or major modifications. \\
& & (3) & Agenda for future research. \\
\hline
\end{tabular}




\begin{tabular}{|ll|ll|}
\hline 4. & METHODS & (1) & Methods for collection. \\
& & (2) & Analyse and interpret dates. \\
\hline 5. & OPERATION- & (1) & Operationally define constructions. \\
& AL & (2) & Involve measured development. \\
& & (3) & Mathematical specifications. \\
\hline
\end{tabular}

Table 8. Number of Articles Based on Article Characteristic of the Top 30 Most Cited SERVQUAL Articles (1998-2013)

\begin{tabular}{|c|c|c|c|c|c|}
\hline Year Published & EMPIRICAL & METHOD & THEORY & OPERATIONAL & TOTAL \\
\hline 1998 & 1 & & & & 1 \\
\hline 1999 & 3 & 1 & 1 & & 5 \\
\hline 2000 & 3 & & 1 & & 4 \\
\hline 2001 & 1 & 1 & 1 & 1 & 4 \\
\hline 2002 & 2 & 1 & 1 & & 5 \\
\hline 2003 & 3 & 1 & & & 4 \\
\hline 2004 & 2 & & & & 2 \\
\hline 2005 & 2 & & & & 2 \\
\hline 2006 & 1 & & 1 & & 2 \\
\hline 2009 & & 1 & & & 1 \\
\hline Total & $\mathbf{1 8}$ & $\mathbf{5}$ & $\mathbf{5}$ & $\mathbf{2}$ & $\mathbf{3 0}$ \\
\hline
\end{tabular}

\section{Conclusions and Future Work}

In this paper we discuss research contribution of the SERVQUAL model from 367 SSCI and SCI journals articles between 1998 and 2013. We identify key factors and conduct a survey to search for related articles in the ISI Web of Science database. We present the results of our survey with quantitative and qualitative metrics, such as the number of publications by year, categorization of article types, key publication venues and contributors, the most cited articles, and article characteristics.

Our study shows that the number of articles on the SERVQUAL model in-creased from a time perspective. Our results further provide support for many research trends and impacts on various key factors. These trends are usually correlated with internet era and blooming of e-commerce. We see a shift of areas of interest for ser-vice quality over the studied period. Economic growth and government policies and strategies also play roles in helping promote service quality research from a geographic perspective. In addition, the SERVQUAL research remains focused on identifying the key factors of service quality based upon the SERVQUAL Model in the EM-PIRICAL category.
We have employed different metrics to evaluate research contribution in the arti-cles we studied. Number of Publications and Number of Citations alone might not reveal the true research contribution of researchers, institutions, journals, and countries. We show this by correlating the number of publications and number of times cited. It is evident that we need a better metric that combined research productivity/quantity and impact/quality.

Our future work includes identifying more impact factors in our survey, and use robust and unified metrics like Hirsch index for research contribution to help re-searchers better understand the SERVQUAL model.

\section{References}

[1] A. Parasuraman, V. A. Zeithaml, and L. L. Berry, "A Conceptual Model of Service Quality and Its Implications for Future Research," Journal of Marketing, vol. 64, no. 4, pp. 41-50, Autumn 1985.

[2] A. Parasuraman, V. A. Zeithaml, and L. L. Berry, "Servqual: A multiple-item scale for measuring consumer perceptions of service quality," Journal of Retailing, vol. 64, no. 1, pp. 12-40, 1988.

[3] T. Luor, R. E. Johanson, H.-P. Lu, and L.-1. $\mathrm{Wu}$, "Trends and Iacunae for future 
computer assisted learning (CAL) research: An assessment of the literature in SSCI journals from 1998-2006," Journal of the American Society for Information Science and Technology, vol. 59, pp. 1313-1320, June 2008.

[4] J. Mingers, "Measuring the research contribution of management academics using the Hirsch-index," The Journal of the Operational Research Society, vol. 60, pp. 1143-1153, September 2009.

[5] HIRSCH, Jorge E. "An index to quantify an individual's scientific research output," in Proc. The National Academy of Sciences, vol. 102, no. 46, USA, 2005, pp. 16569-16572.

[6] J. A. Cote, S. M. Leong, and J. Cote, "Assessing the Influence of Journal of Consumer Research: A Citation Analysis," Journal of Consumer Research, vol. 18, pp. 404-410, December 1991.

[7] M. K. Brady and J. J. Cronin Jr, "Some new thoughts on conceptualizing perceived service quality: a hierarchical approach," Journal of Marketing, vol. 65, pp. 34-49, July 2001.

[8] D. A. Baker and J. L. Crompton, "Quality, satisfaction and behavioral intentions," Annals of Tourism Research, vol. 27, no. 3, pp. 785-804, July 2000.

[9] P. A. Dabholkar, C. D. Shepherd, and D. I. Thorpe, "A comprehensive framework for service quality: An investigation of critical conceptual and measurement issues through a longitudinal study," Journal of Retailing, vol. 76, no. 2, pp. 139173, Summer 2000.

[10] S. Devaraj, M. Fan, and R. Kohli, "Antecedents of B2C channel satisfaction and preference: Validation e-Commerce metrics," Information Systems Research, vol. 13, pp. 316-333, September 2002.

[11] J. T. Mentzer, D. J. Flint, and G. T. M. Hult, "Logistics service quality as a segment-customized process," Journal of Marketing, vol. 65, pp. 82-104, October 2001.

[12] J. E. Collier and C. C. Bienstock, "Measuring service quality in eretailing," Journal of Service Research, vol. 8, no. 3, pp. 260-275, February 2006.

[13] M. K. Brady, J. J. Cronin Jr, and R. R. Brand, "Performance-only measurement of service quality: a replication and extension," Journal of Business Research, vol. 55, no. 1, pp. 17-31, January 2002.

[14] J. J. Jiang, G. Klein, and C. L. Carr, "Measuring information system service quality: SERVQUAL from the other side," Mis Quarterly, vol. 26, no. 2, pp. 145-166, June 2002.

[15] S. J. Barnes and R. Vidgen, "An evaluation of cyber-bookshops: the WebQual method," International Journal of Electronic Commerce, vol. 6, pp. 11-30, December 2014.

[16] M. Cao, Q. Zhang, and J. Seydel, "B2C e-commerce web site quality: an empirical examination," Industrial Management \& Data Systems, vol. 105, no. 5, pp. 645661, 2005.

[17] K. L. Wakefield and J. G. Blodgett, "Customer response to intangible and tangible service factors," Psychology \& Marketing, vol. 16, no. 1, pp. 51-68, January 1999.

[18] S. S. Andaleeb, "Service quality perceptions and patient satisfaction: a study of hospitals in a developing country," Social Science \& Medicine, vol. 52, no. 9, pp. 1359-1370, May 2001.

[19] R. T. Watson, L. F. Pitt, and C. B. Kavan, "Measuring information systems service quality: lessons from two longitudinal case studies," Mis Quarterly, vol. 22, no. 1, pp. 61-79, March 1998.

[20] Y. Li, K. Tan, and M. Xie, "Measuring web-based service quality," Total Quality Management, vol. 13, no. 5, pp. 685-700, 2002.

[21] M. A. Badri, "A combined AHP-GP model for quality control systems," International Journal of Production Economics, vol. 72, no. 1, 2001 pp. 27-40, June 2001.

[22] F. X. Zhu, W. Wymer, and I. Chen, "ITbased services and service quality in consumer banking," International Journal of Service Industry Management, vol. 13, no. 1, pp. 69-90, 2002. 
[23] S. E. Sampson and M. J. Showalter, "The performance-importance response function: Observations and implications," Service Industries Journal, vol. 19, pp. 125, 1999.

[24] J. S. Akama and D. M. Kieti, "Measuring tourist satisfaction with Kenya's wildlife safari: a case study of Tsavo West National Park," Tourism Management, vol. 24, pp. 73-81, February 2003.

[25] W. J. Kettinger and C. C. Lee, "Zones of tolerance: alternative scales for measuring information systems service quality," Mis Quarterly, pp. 607-623, December 2005.

[26] Y. Wang, H.-P. Lo, and Y. Yang, “An integrated framework for service quality, customer value, satisfaction: evidence from China's telecommunication industry," Information Systems Frontiers, vol. 6, pp. 325-340, December 2004.

[27] D. Gilbert and R. K. Wong, "Passenger expectations and airline services: a Hong Kong based study," Tourism Management, vol. 24, pp. 519-532, October 2003.

[28] C. Homburg and B. Rudolph, "Customer satisfaction in industrial markets: dimensional and multiple role issues," Journal of Business Research, vol. 52, pp. 15-33, April 2001.

[29] T. P. Dyke, V. R. Prybutok, and L. A. Kappelman, "Cautions on the use of the SERVQUAL measure to assess the quality of information systems services," Decision Sciences, vol. 30, pp. 877-891, June 1999.

[30] M.-L. Tseng, "A causal and effect decision making model of service quality expectation using grey-fuzzy DEMATEL approach," Expert Systems with Applications, vol. 36, pp. 7738-7748, May 2009.

[31] M. M. Espinoza, "Assessing the crosscultural applicability of a service quality measure a comparative study between Quebec and Peru," International Journal of Service Industry Management, vol. 10, pp. 449-468, 1999.

[32] H. Landrum and V. R. Prybutok, "A service quality and success model for the information service industry," European Journal of Operational Research, vol. 156, pp. 628-642, August 2004.

[33] A. Caruana, M. T. Ewing, and B. Ramaseshan, "Assessment of the threecolumn format SERVQUAL: an experimental approach," Journal of Business Research, vol. 49, pp. 57-65, July 2000.

[34] A. J. Verdú Jover, F. J. Lloréns Montes, and M. a. d. M. Fuentes Fuentes, "Measuring perceptions of quality in food products: the case of red wine," Food Quality and Preference, vol. 15, pp. 453-469, July 2004.

[35] J. J. Jiang, G. Klein, and S. M. Crampton, "A note on SERVQUAL reliability and validity in information system service quality measurement," Decision Sciences, vol. 31, pp. 725-744, September 2000.

[36] T. Lam and H. Q. Zhang, "Service quality of travel agents: the case of travel agents in Hong Kong," Tourism Management, vol. 20, pp. 341-349, June 1999.

[37] H.-H. Tsai and I.-Y. Lu, "The evaluation of service quality using generalized Choquet integral," Information Sciences, vol. 176, pp. 640-663, March 2006.

Appendix A. Category and Times Cited of Top 30 SERVQUAL Articles (1998-2013)

\begin{tabular}{|c|c|c|}
\hline Author/Publish year/Title/Journal Name & Category & $\begin{array}{l}\text { Times } \\
\text { Cited }\end{array}$ \\
\hline $\begin{array}{l}\text { 1. Devaraj, S., Fan, M., and Kohli, R. (2002), “Antecedents } \\
\text { of B2C channel satisfaction and preference: Validating } \\
\text { e-commerce metrics," INFORMATION SYSTEMS RE- } \\
\text { SEARCH, } 13(3), 316-333 \text { [10] }\end{array}$ & EMPIRICAL & 269 \\
\hline $\begin{array}{l}\text { 2. Baker, D. A. and Crompton, J. L. (2000), "Quality, Sat- } \\
\text { isfaction and behavioral intentions," ANNALS OF }\end{array}$ & THEORY & 254 \\
\hline
\end{tabular}




\begin{tabular}{|c|c|c|c|}
\hline & TOURISM RESEARCH, 27 (3), 785-804 [8] & & \\
\hline & $\begin{array}{l}\text { Dabholkar, P. A., Shepherd, C. D., and Thorpe, D. I. } \\
\text { (2000), "A comprehensive framework for service quali- } \\
\text { ty: An investigation of critical conceptual and measure- } \\
\text { ment issues through a longitudinal study," JOURNAL } \\
\text { OF RETAILING, } 76(2), 139-173 \text { [9] }\end{array}$ & THEORY & 177 \\
\hline & $\begin{array}{l}\text { Mentzer, J. T., Flint, D. J., and Hult, T. M. (2001), "Lo- } \\
\text { gistics service quality as a segment-customized process," } \\
\text { JOURNAL OF MARKETING, } 65 \text { (4), 82-104 [11] }\end{array}$ & EMPIRICAL & 152 \\
\hline & $\begin{array}{l}\text { Collier, J. E. and Bienstock, C. C. (2006), "Measuring } \\
\text { service quality in e-retailing," JOURNAL OF SERVICE } \\
\text { RESEARCH, } 8 \text { (3), 260-275. [12] }\end{array}$ & $\begin{array}{l}\text { OPERATION- } \\
\text { AL }\end{array}$ & 114 \\
\hline & $\begin{array}{l}\text { Brady, M. K., Cronin, J. J., and Brand, R. R. (2002), } \\
\text { "Performance-only measurement of service quality: A } \\
\text { replication and extension," JOURNAL OF BUSINESS } \\
\text { RESEARCH, } 55 \text { (1), 17-31 [13] }\end{array}$ & THEORY & 113 \\
\hline & $\begin{array}{l}\text { Jiang, J. J., Klein, G., and Carr, C. L. (2002), "Measur- } \\
\text { ing information system service quality: Servqual from } \\
\text { the other side," MIS QUARTERLY, } 26 \text { (2), 145-166 } \\
{[14]}\end{array}$ & EMPIRICAL & 94 \\
\hline & $\begin{array}{l}\text { Barnes, S. J. and Vidgen, R. (2001), "An evaluation of } \\
\text { cyber-bookshops: The webqual method," INTERNA- } \\
\text { TIONAL JOURNAL OF ELECTRONIC COMMERCE, } \\
6(1), 11-30[15]\end{array}$ & EMPIRICAL & 86 \\
\hline & $\begin{array}{l}\text { Cao, M., Zhang, Q. Y., and Seydel, J. (2005), "B2C e- } \\
\text { commerce web site quality: An empirical examination," } \\
\text { INDUSTRIAL MANAGEMENT \& DATA SYSTEMS, } \\
105(5-6), 645-661 \text { [16] }\end{array}$ & METHODS & 77 \\
\hline & Author/Publish Year/Title/Journal Name & Category & $\begin{array}{l}\text { Times } \\
\text { Cited }\end{array}$ \\
\hline & $\begin{array}{l}\text { Wakefield, K. L. and Blodgett, J. G. (1999), "Customer } \\
\text { response to intangible and tangible service factors," } \\
\text { PSYCHOLOGY \& MARKETING, } 16 \text { (1), 51-68 [17] }\end{array}$ & EMPIRICAL & 76 \\
\hline & $\begin{array}{l}\text { Andaleeb, S. S. (2001), "Service quality perceptions and } \\
\text { patient satisfaction: a study of hospitals in a developing } \\
\text { country," SOCIAL SCIENCE \& MEDICINE, 52 (9), } \\
1359-1370 \text { [18] }\end{array}$ & THEORY & 72 \\
\hline & $\begin{array}{l}\text { Watson, R. T., Pitt, L. F., and Kavan, C. B. (1998), } \\
\text { "Measuring information systems service quality: Les- } \\
\text { sons from two longitudinal case studies," MIS QUAR- } \\
\text { TERLY, } 22 \text { (1), 61-79 [19] }\end{array}$ & THEORY & 65 \\
\hline & $\begin{array}{l}\text { Li, Y. N., Tan, K. C., and Xie, M. (2002), "Measuring } \\
\text { web-based service quality," TOTAL QUALITY MAN- } \\
\text { AGEMENT, } 13 \text { (5), 73-81 [20] }\end{array}$ & EMPIRICAL & 59 \\
\hline & $\begin{array}{l}\text { Badri, M. A. (2001), "A combined AHP-GP model for } \\
\text { quality control systems," INTERNATIONAL JOUR- } \\
\text { NAL OF PRODUCTION ECONOMICS, } 72 \text { (1), 27-4 } \\
{[21]}\end{array}$ & METHODS & 56 \\
\hline & $\begin{array}{l}\text { Zhu, F. X., Wymer, W., and Chen, I. (2002), "IT-based } \\
\text { services and service quality in consumer banking," IN- }\end{array}$ & EMPIRICAL & 55 \\
\hline
\end{tabular}




\begin{tabular}{|c|c|c|c|}
\hline & $\begin{array}{l}\text { TERNATIONAL JOURNAL OF SERVICE INDUS- } \\
\text { TRY MANAGEMENT, } 13(1), 69-90 \text { [22] }\end{array}$ & & \\
\hline & $\begin{array}{l}\text { Sampson, S. E. and Showalter, M. J. (1999), "The per- } \\
\text { formance-importance response function: Observations } \\
\text { and implications," SERVICE INDUSTRIES JOURNAL, } \\
19(3), 1-25[23]\end{array}$ & $\begin{array}{c}\text { OPERATION- } \\
\text { AL }\end{array}$ & 53 \\
\hline & $\begin{array}{l}\text { Akama, J. S. and Kieti, D. M. (2003), "Measuring tourist } \\
\text { satisfaction with Kenya's wildlife safari: a case study of } \\
\text { Tsavo West National Park," TOURISM MANAGE- } \\
\text { MENT, } 24(1), 73-81[24]\end{array}$ & EMPIRICAL & 52 \\
\hline & $\begin{array}{l}\text { Kettinger, W. J. and Lee, C. C. (2003), "Zones of toler- } \\
\text { ance: Alternative scales for measuring information sys- } \\
\text { tems service quality," MIS QUARTERLY, } 24 \text { (1), 607- } \\
623[25]\end{array}$ & EMPIRICAL & 49 \\
\hline & Author/Publish Year/Title/Journal Name & Category & $\begin{array}{l}\text { Times } \\
\text { Cited }\end{array}$ \\
\hline & $\begin{array}{l}\text { Wang, Y. G., Lo, H. P., and Yang, Y. H. (2004), “An in- } \\
\text { tegrated framework for service quality, customer value, } \\
\text { satisfaction: Evidence from China's telecommunication } \\
\text { industry," INFORMATION SYSTEMS FRONTIERS, } 6 \\
(4), 325-340 \text { [26] }\end{array}$ & EMPIRICAL & 49 \\
\hline & $\begin{array}{l}\text { Gilbert, D. and Wong, R. K. C. (2003), " Passenger ex- } \\
\text { pectations and airline services: a Hong Kong based } \\
\text { study," TOURISM MANAGEMENT, } 24 \text { (5), 519-532 } \\
{[27]}\end{array}$ & EMPIRICAL & 48 \\
\hline & $\begin{array}{l}\text { Homburg, C. and Rudolph, B. (2001), "Customer satis- } \\
\text { faction in industrial markets: dimensional and multiple } \\
\text { role issues," JOURNAL OF BUSINESS RESEARCH, } \\
52(1), 15-33 \text { [28] }\end{array}$ & EMPIRICAL & 46 \\
\hline & $\begin{array}{l}\text { Van Dyke, T. P., Prybutok, V. R., and Kappelman, L. A. } \\
\text { (1999), "Cautions on the use of the SERVQUAL meas- } \\
\text { ure to assess the quality of information systems ser- } \\
\text { vices.," DECISION SCIENCES, } 30(3), 877-891[29]\end{array}$ & METHOD & 45 \\
\hline 23. & $\begin{array}{l}\text { Tseng, M-L. (2009), "A causal and effect decision mak- } \\
\text { ing model of service quality expectation using grey- } \\
\text { fuzzy DEMATEL approach," EXPERT SYSTEMS } \\
\text { WITH APPLICATIONS, } 36(4), 7738-7748[30]\end{array}$ & METHOD & 38 \\
\hline & $\begin{array}{l}\text { Espinoza, M. M. (1999), "Assessing the cross-cultural } \\
\text { applicability of a service quality measure - A compara- } \\
\text { tive study between Quebec and Per," INTERNATION- } \\
\text { AL JOURNAL OF SERVICE INDUSTRY MANAGE- } \\
\text { MENT, } 10(5), 449-468 \text { [31] }\end{array}$ & METHOD & 38 \\
\hline 25. & $\begin{array}{l}\text { Landrum, H. and Prybutok, V. R. (2004), "A service } \\
\text { quality and success model for the information service } \\
\text { industry," EUROPEAN JOURNAL OF OPERATION- } \\
\text { AL RESEARCH, } 156(3), 628-642 \text { [32] }\end{array}$ & METHOD & 37 \\
\hline 26. & $\begin{array}{l}\text { Caruana, A., Ewing, M. T., and Ramaseshan, B. (2000), } \\
\text { "Assessment of the three-column format SERVQUAL: } \\
\text { An experimental approach," JOURNAL OF BUSINESS } \\
\text { RESEARCH, } 49 \text { (1), 57-65 [33] }\end{array}$ & EMPIRICAL & 37 \\
\hline
\end{tabular}




\begin{tabular}{|l|c|c|}
\hline \multicolumn{1}{|c|}{ Author/Publish Year/Title/Journal Name } & Category & $\begin{array}{c}\text { Times } \\
\text { Cited }\end{array}$ \\
\hline 27. Jover, A. J. V., Montes, F. J. L., and Fuentes, M. D. F. \\
$\begin{array}{l}\text { (2004), "Measuring perceptions of quality in food prod- } \\
\text { ucts: the case of red wine," FOOD QUALITY AND } \\
\text { REFERENCE, 15 (5), 453-469 [34] }\end{array}$ & EMPIRICAL & 36 \\
\hline 28. Jiang, J. J., Klein, G., and Crampton, S. M. (2000), “A \\
$\begin{array}{l}\text { note on SERVQUAL reliability and validity in infor- } \\
\text { mation system service quality measurement," DECI- } \\
\text { SION SCIENCES, 31 (3), 725-744 [35] }\end{array}$ & EMPIRICAL & 34 \\
\hline 29. $\begin{array}{l}\text { Lam, T. and Zhang, H. Q. Q. (1999), " Service quality of } \\
\text { travel agents: the case of travel agents in Hong Kong," } \\
\text { TOURISM MANAGEMENT, 20 (3), 341-349 [36] }\end{array}$ & EMPIRICAL & 33 \\
\hline 30. $\begin{array}{l}\text { Tsai, H. H. and Lu, I. Y. (2006), "The evaluation of ser- } \\
\text { vice quality using generalized Choquet integral," IN- } \\
\text { FORMATION SCIENCES, 176 (6), 640-663 [37] }\end{array}$ & EMPIRICAL & 32 \\
\hline
\end{tabular}

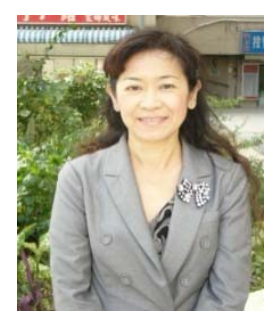

Ya Lan WANG received her Executive MBA degree from National Taiwan University of Science and Technology (NTUST), Taiwan, in 2013. She is currently a Ph.D. student of School of Management at NTUST. Ya Lan has over 20 years of experience in corporate training and 6 years of experience in sales and marketing. She has conducted corporate training for many fortune-100 companies in both China and Taiwan since 2002. Her professional and research interests include: creative thinking, corporate training, customer service, selling skills, and service quality.

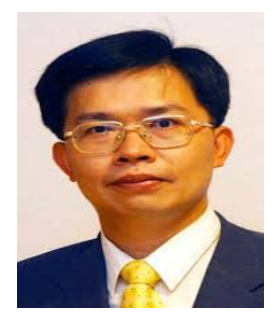

Tainyi LUOR is a part time Associate Professor in the National Taiwan University of Science and Technology Graduate School of Management (Taipei, Taiwan, R.O.C.) and General Manager of the Information Management at the International Bills Finance Corporation. His research interests involve the implementation of CAL. applications into financial management issues and webbased business applications.

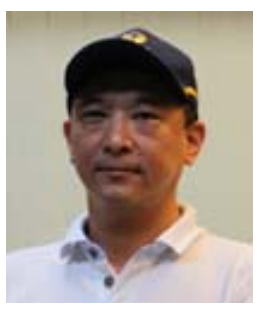

Pin LUARN is a professor at the School of Management, National Taiwan University of Science and Technology, Taiwan. He received his $\mathrm{PhD}$ in industrial Engineering from University of Wisconsin, USA. Professor Luarn's researches include e-commerce, internet marketing and social network service.

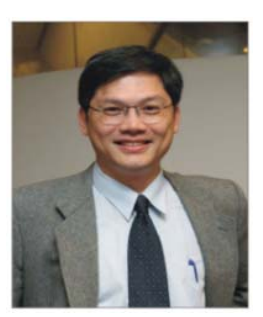

Hsi-peng $\mathbf{L} \mathbf{U}$ is a Professor in the Department of Information Management and the Dean of the National Taiwan University of Science and Technology (Taipei, Taiwan, R.O.C.) 